\title{
SCHOOL ETHOS AND ITS RELIGIOUS DIMENSION
}

\author{
Cok Bakker \\ Utrecht University \\ Ina ter Avest \\ CHN University at Leeuwarden \\ The Netherlands
}

\begin{abstract}
In the Netherlands the debate on the identity of a school is influenced by the long and dominant history of a close linking between religious traditions (mainly the Christian tradition) and the design of the national school system. For almost 100 years, most schools, formally speaking, are so called Christian schools. This is not an accidental adverb used to indicate some of the Dutch schools, but it has a strong juridical basis. In recent education a certain discrepancy is experienced between the formal corporate identity of a school and the actual identity of the school population. This discrepancy is the central matter of this article. We present two research projects by which this discrepancy is explored. The key issue seems to be that in Dutch education there is a strong need for a paradigm shift from a more deductive to a more inductive reflection on school ethos.
\end{abstract}

Key Concepts: School ethos, Christian schools, identities, discrepancy

\section{Introduction}

In an international comparative study on the relationship between religion and education it will always be important to understand and to recognise the influence of the societal and organisational context of the educational system of each specific country. Focusing on the situation and practices in the Netherlands, it is essential to understand how educational policy is strongly determined by Article 23 of the Constitution. This article proclaims the right of all people (!) to establish a school and to organise and provide education. Of course, this right is related to certain basic criteria of quality and quantity, but in principle everyone is free to set up schools by private initiative (compared in the international context, it is quite remarkable that the government pays for the education in schools whoever the group that runs the school). In addition to these private initiatives, the state provides public education.

\section{A Pillarised System of Education in Modern Times}

This dual system might be understood as the rather common distinction between public schools (openbare scholen) and private schools (bijzondere scholen), but comparing it with the situation in other countries, it is very important to realise that the state pays the costs of running all schools. This is a crucial difference. Almost one century of this educational policy ${ }^{1}$ has led to a rather rigid pillarised system (verzuiling): Education is organised on specific philosophical, religious and/or pedagogical foundations, according to certain

The freedom of education, including the equalisation of the financial treatment of public and private schools, has been guaranteed by law since 1921 . 
(Christian) traditions and the same types of schools are clustered in separate and rather isolated pillars. In the past, including the recent past, these pillars functioned largely independently from each other. And, let us say, before 1960 this pillarised landscape was not only true in education - it was the whole of Dutch society that was organised in $s u b$ societies, that has been named pillars (zuilen). It is only in the last decades that, due to this pillarisation, some fundamental questions have been raised.

Public schools account for only $25 \%$ of schools. The remaining $75 \%$ being private schools provide education from a specific religious background, or a specific pedagogical or philosophical context. Examples of these schools are Roman Catholic, Protestant, Islamic, Jewish, Hindu, Montessori, Jenaplan, Waldorf (Dutch: vrije scholen) schools and others. It is remarkable that of the total number of Dutch schools, about $30 \%$ are Roman Catholic and roughly another $30 \%$ is Protestant. Of the $15 \%$ of private schools left, several only have a specific pedagogical or philosophical background, but some also regard themselves as being in the Christian tradition. This means that about $65 \%$ of the schools in the Netherlands are, formally speaking, Christian schools. It is important to remember this in any discussion on the religious dimensions within the Dutch education setting.

In today's situation many things have changed. This has implications for the way education and Christian education is positioned and legitimised. Generally speaking on the macro-level of society, it is clear that the present Dutch society is a secularised, multicultural and religiously plural society. More than 1.5 million inhabitants (out of app. 16 million) have their roots in other countries and cultures. A small number of them were born in other Western countries, but most of them come from or have their roots in countries with other, non-Western cultures. This very often implies that they belonged or belong to non-Christian religious traditions. Most of the ethnic minorities come from Morocco and Turkey and most of them have a Muslim background. The second largest group are people from Surinam with Hindu, Christian or Muslim backgrounds. In addition to this notion of an increase in ethnic, cultural and religious diversity (since the sixties), there has also been a move towards secularisation. Approximately $60 \%$ of Dutch people formally belong to some church or religious group, but only $25 \%$ attend services on a regular basis (once a month or more).

Now we have the matter clear: In Dutch society, described here briefly as being religiously diverse and secularised, more than $65 \%$ of schools are Christian schools (Protestant and Roman Catholic schools). It seems reasonable to expect that since the sixties - parallel to the developments in society - a certain discrepancy has developed between the formal corporate identity of a school and the actual identity of the school population.

This discrepancy is exactly what grounded our interest. It is also one of the most important stimuli to run the research projects we do with our group. Two of these projects are presented in this article. We present some of the results and we share some related experiences. The central theme is - and this is the claim we put forward from our research that in the Dutch educational society there is a strong need for a paradigm shift from a more deductive to a more inductive reflection on school ethos. On the one hand this proves to be a difficult turn, since it proves to be a rather fundamental change. On the other hand, focussing on the biography of teachers and their role in constructing identity of a school instead of just implementing a concept of Christian education, research has made clear that the inductive approach is a challenging new perspective in this debate. We elaborate this argument at a later stage. 


\section{Two of Utrecht's Research Projects}

We have explored this paradigm shift by two research projects that we presented at the Stellenbosch conference in 2004:

Firstly by the presentation of the results of a (A) qualitative empirical research project on the (religious) biographies of teachers of religiously affiliated schools, entitled Teacher on a tense footing; and secondly by the description of our efforts (B) to facilitate structural debates within separate schools to stimulate reflection and to trigger more contextually based interpretations of Christian education. Our presupposition is that a contextual interpretation is also a more authentic interpretation.

We see this structural and contextualised debate on the Christian identity of a school in every single school as a very promising perspective - opposed to a more or less implicit deductive perception of Christian identity. For our team this second project offers opportunities to reflect on this new and experimental approach. It is therefore the experimental garden for our researchers, together with the close cooperation with the teachers and headmasters of the schools involved.

\section{Perception of the School's Identity}

Before we present and concentrate on these two projects we explore two alternative ways of perceiving the formal (Christian) identity of a Dutch school. We work with a simple but effective model trying to get a grip on processes regarding the identity of a school. The model assists in discovering pitfalls and to unmask the creation of non-effective images. Concerning the Christian ethos of a school, in this model, we distinguish between a deductive reasoning mechanism (= Reasoning $\mathrm{A}$ ) and an inductive reasoning mechanism (= Reasoning B; cf. Bakker, in: Miedema and Vroom, 2002:101).

In the mechanism of Reasoning $A$, a specific concept (a specific interpretation of the Christian identity of a school) precedes the development of educational processes in the school. The ideal of that line of argument is that practice is cultivated and modelled by the concept. The central principles of the school and its foundation are perceived independently from the daily practices in the school. Daily practice is supposed to be derived deductively from the Christian identity concept. In the majority cases, this is done more or less implicitly. An inter-active relationship between the dynamics of the daily practice and the position and impact of the steering principles, is not taken into account. The regulating concept could have all kinds of contents and shapes; e.g. it could be a specific Dutchreformed theology, a concept of open catholic education, the concept of active plurality as it is proclaimed in the pillar of the Dutch public schools, it could be a Hindu educational concept based on the Karmavidian tradition, or a specific pedagogical context (e.g. Maria Montessori's Method). All these concepts are, in the mechanisms of Reasoning A, perceived, experienced and very often cherished as absolute values. They are perceived as guarantees for good or even the best education. Once chosen for such a specific concept, the next job is to elaborate these concepts and to translate them into good daily practices.

Reasoning B puts the opposite down and starts at the other side. Whether there has been a lot of deep thinking on the principles and foundation of a school or not, unavoidably a school has specific characteristics; in other words, a unique identity. An identity is always obvious for all to observe. A series of daily practices in the school generate an image of what type of school it is... To put it in a more popular phrase, rather independent from chosen concepts, the rumours about the school in the quarter or among the parents could also be seen as an identity perception. This could be a positive or a negative image, but in 
the talks an image of the school itself exists ... Identity perceived in this way starts with a thick description of daily practice, such as the talks of the parents about the school. But many, many more variables could be analysed additionally: For example, the thinking and decision-making of teachers, the management-style of the principal, how children experience education, topical social behaviour, the architecture of the school-building, etcetera. After such an observation and analysis, the school's culture could be described and established. In this approach the school's identity is not prescribed beforehand, but is established afterwards. The consequence of the mechanism of Reasoning B is that the identity of the school is interpreted as being dynamic. It is only the description and analysis of one moment, and not a rigid, well-described and unchangeable entity for a period of, let us say five years - or may be even for eternity. Schools acquire and generate identity all the time - an identity that could be described on a certain moment but that is only the description on a specific point in time. Major and minor events in daily practices could also have an influence on the observations of a previous moment. Identity perceived in this way is essentially inductive in its mechanisms.

In contemporary literature we see a notion towards this alternative way of reasoning both in the Dutch debate ${ }^{2}$ and in an international context. ${ }^{3}$ This notion is reflected in many ways in the field of education, but also in the broader perspective of the public domain. In general, we can perceive a more inductive, contextually oriented, interpretative approach of religious traditions as an integral part of culture. ${ }^{4}$ This is mirrored in a smaller scale within the Christian identity (or identities) of an institution.

In the field of education a quite simple but effective observation often evokes the proper and necessary discussion: Two schools with a similar concept of Christian education (cf. Reasoning A) or even two schools belonging to the same governing body quite easily could differ in their cultures and in the way their concrete educational acts are developed. How could that be? These differences occur because some of the mechanism of Reasoning B becomes evident. Apparently there is more in the fire than just the selection of a good concept of education and the formal commitment to a certain religious tradition. Besides this variable, other variables are also playing a role, such as the individual commitments of teachers (they may even be divided among themselves), the (religious) backgrounds of children, individual interpretations among the members of the board, the parents, and sometimes even the external expectations of the professional field.

Having said this, by developing our research-projects we presuppose that the formal identity of religiously affiliated schools does not precede the thinking and acting of the teacher, but that the topical identity, the topical ethos, arises from and gets its shape from the thinking and acting of the teachers of a single school. This includes all aspects of the continuous, verbal and non-verbal communicative processes that are part of the school processes. The formation of identity does not only operate deductively, but also emphatically features in an inductive mechanism. Morality arises from the lasting interaction between the members of a specific and concrete community (cf. Taylor, 1994; Durkheim, 1992; Klaassen 1996).

Miedema, 2003; Hermans, 2002, 2003; Roebben, 2000; De Wolff, 2000; Bakker, 2004a/b

Jackson, 1997, 2004; Heimbrock, Scheilke and Schreiner, 2001; Chidester, Stonier and Tobler, 1999; Rickers and Siedler, 2001; Bakker and Griffioen, 2001.

4 Durkheim, 1992; Jackson, 1997; Giddens, 1986; Beck, 1986; Kunneman, 1996, 1997; Vroom, 1996; Taylor, 1994. 


\section{The Contextual Approach}

This re-orientation regarding the notion of identity of a school is not entirely new. The complex process of redefining the notion has taken place and is still taking place. Convincing - may be for all - is the observation that schools within the same pillar might differ from each other. Or stronger, you could be sure about that. At the most we could talk about a certain family resemblance within a pillar in stead of a steady homogeneity (Dutch: familie-gelijkenis; Kuiper, 1994). This is mirrored on the concrete level of the organisation of groups of schools within the same foundation - there is a readiness to admit and agree upon the differences among themselves; as we find: An acknowledged difference (Bakker and Ter Avest, 2003). After a thorough and extensive conceptual exploration of the notion identity of a school, De Wolff (2000) redefines this notion as follows:

The identity of a school is 'what makes a school into this school', or: 'what the outstanding features are of this school (both in a characteristic and a distinguishing sense)', and 'what the members of the school have in common, what they share, what is true for them as members of the collective community and what could be characterised by a certain degree of durability and continuity' (De Wolff, 2000:53).

It is clear that this definition primarily focuses on the single and concrete school. It is about a specific school, with a specific teaching-team, in a specific context. This definition is contrary to a definition that makes the identity of a specific school dependent from the identity of the pillar or the identity of the governmental board, in a more-or-less deductive relationship. We agree with the re-orientation of the first definition.

The contextualisation of the notion of identity of the school does not necessarily mean that the realised school ethos is not in a specific inter-relationship with a specific body of knowledge, a religious tradition or philosophy from outside the school. Certainly external points of reference could play a role. A specific philosophy or ideology could be a strong landmark and could assist teachers to orientate themselves on what could be cited as good education. We would argue that in this contextual approach the Christian tradition or, e.g. the ideas of Maria Montessori, could be very valuable and influential. But essential is the contextual and non-objective influence of these ideas and insights. It is through a unique process by means of unique interpretations and manifestations that these ideas are influencing the daily practices in a specific school.

In other words, there is a tendency towards the acknowledgement of the moral effects of individual characteristics and contextual factors. This could be illustrated in the area of teacher education and the increasing attention that is paid to the individual characteristics of the teacher and his or her individual biography. We could even speak about a trend and we could think of Kelchtermans (1990; 1991), Van den Berg and Vandenberghe (1995), Korthagen (1998; 2001), Korthagen c.s. (2001, 1996), Everington and Sikes (1998) and many other authors interested in the subjective educational concepts that are in the mind of the student-teacher. For the professional development of both student-teachers and fullteachers, we have to be aware of these subjective concepts. Not to deny them or to overrule those by the central concept, but to take those serious and even work with them in the training programme (Van den Berg and Ros, 1998; Van Parreren, 1988). It is the grown awareness in the thinking on teacher education that fully wants to take into account the individualised, context-based systems of meaning as dynamic, mental constructs - an

5 In Dutch: datgene wat de school tot déze school maakt, oftewel wat de kenmerkende (typerende of onderscheidende) eigenschappen van deze school zijn, wat de leden van de school met elkaar gemeen hebben (of wat geldt voor de leden als collectief) en wat een bepaalde mate van duurzaamheid of continuiteit door de tijd kent (De Wolff, 2000:53). 
awareness that has been growing during the last decade but that definitely goes back at least to the philosophy of Dewey (1938).

With our eye on conducting research on the relationship between religion and the formal Christian identity of a school on the one hand, and the actual practices in the school as a moral community on the other hand, we learn that the meaning, contents and impact of that formal identity is greatly dependent on the individual interpretations of - first - every single teacher and - second - of the group of teachers that actually teach. Individual interpretations - opposite to the big Stories - prove to be crucial. (Cf. Wardekker and Miedema, 2001; Hermans, 2002; Roebben, 2000; Lanser, 2000; Jackson, 1997; Bakker, 1999, 2001; Zondag, 1993).

\section{Project A: Teachers on a Tense Footing}

Taking this presupposition seriously we developed a research-project. It is quite easy to see that from the remarks we made at the start of this article that a field of tension could be constructed. On the one hand many schools in the Netherlands with have an explicit Christian identity and on the other hand the religious pluralism and secularisation in society. This field of tension could be manifest in an average religiously affiliated townschool. The questions that arise from this may sound like: A Christian school with Muslim children, how could this be legitimised? Why do we want this? Or why should this be corrected? etc. In line with this, one could naively presume that this field of tension is also in the mind of the teacher. If we, however, consider the crucial individual interpretations of teachers then this is a new and serious question without standardised answers. What is true in this matter?

Knowing the variety of interpretations that precede the teacher's reconstruction of a field of tension, we developed the following problem as the starting point for the whole project:

Looking back on their professional career and on their individual biography, how do teachers of Christian schools interpret their professional thinking and acting concerning the formal Christian identity of the school and the relative decrease of the number of children with a Christian background ${ }^{6}$

This central research question was elaborated in several sub-questions. One of them is: The teacher at work in the field of tension between the component Formal Christian identity of the school and the component Religious diversity in the school and in the classroom, does he or she actually experience and interpret that as a strained relationship?

The research strategy included a series of repetitive interviews with eleven teachers. These teachers are experienced teachers with a teaching-career of at least ten years; they all work in different Christian schools, in multi-cultural and multi-religious contexts. As the research question shows, a biographical perspective was taken. The series of interviews resulted in a qualitative empirical analysis of a huge quantity of data. The analysis led to the construction of a portrait of every single teacher in which his or her perception of the formal identity of the school, the religious diversity in the school and classroom and the possible perceived tension between the two is described. After the reconstruction of the individual portraits a cross analysis was made. In a qualitative empirical research design the

6 Bakker, Cok and Elizabeth Rigg (2004). De persoon van de leerkracht; Tussen christelijke schoolidentiteit en leerlingendiversiteit. Zoetermeer: Meinema. And Bakker, Cok and Elizabeth Rigg (2003). De leerkracht op gespannen voet?; Levensbeschouwing en professionaliteit in biografisch perspectief. Onderzoeksrapport. Utrecht: Universiteit Utrecht. 
purpose is primarily not to gain insight in the research-group as a whole (all teachers at Christian schools in the Netherlands), but to gain an in-depth insight into reasoning mechanisms and schemes. The purpose was to develop a detailed and a layered image, as an answer to the problem that was posited at the start of this project. An image that would be just and fair towards the complexity of the social reality we were focusing on.

The conclusion of the research project is that the teachers in our research group experience very little tension between the two components that we distinguished in the scheme. We think that this is an interesting result, because from literature as shown before, this field of tension could so easily been drawn.

The possible reconstruction of a field of tension in the mind of the teachers is preceded by reconstructions and interpretations of each of the components separately. In other words, first, you must know how a teacher experiences and perceives the formal identity of the school before you can focus on the possible perception of a field of tension. The same is true for the component religious diversity. So two preceding questions arise:

- Does the teacher relate him/herself strainfully to the formal Christian identity of the school?; and

- Does the teacher relate him/herself strainfully to the religious diversity in the school and in the classroom environments?

Therefore, first, does the teacher relate him/herself strainfully to the formal Christian identity of the school? The answer is yes and no.

No, because in daily practice the teacher is hardly ever challenged to reflect on the implications of the Christian identity of the school and while they hardly bear this notion in mind, it is easy to understand that in daily practice they are not on a tense footing with it. There are few stimuli to reflect upon this. However the answer is also yes. The teacher is in a strained relationship with the formal identity of the school if we realise the specific context of a teacher being involved in a research project. The teachers were brought into a specific situation as research-objects and were explicitly asked to explore the implicit and to make this explicit. In various ways researchers/interviewers have confronted them intensively with the given notions of the Christian identity of their schools. Then, and almost then, they perceive this notion as problematic. It proved to be a hard job for the teacher to find words, name it and explain Christian identity and its impact. They put forward that until then they have not been reflecting on it, and now, challenged to do so, they describe their feelings about the notion as being problematic, it is always that vague and you have the feeling that if you want to work on it you always have the feeling that it is never enough; you always should do more.

It is interesting to see that if the teacher is challenged to reflect on formal identity that this reflection is felt as non-self-evident and that the teacher argues mainly according to the deductive scheme (see Reasoning A) and that in most of the descriptions they have a narrow understanding of Christian identity (i.e. about explicit religious issues).

Does the teacher relate him/herself strainfully to the religious diversity in the school and in the classroom? Hardly. The teacher sees diversity in general - and religious diversity included - as a given fact. A common interpretation seems to be: Religious diversity should not be seen as different from the general problem of diversity. Religious diversity is a problem that is not really problematic. They understand from this observation the need to cope with the pluralism in their school and especially in their groups. But this is what you always do. One of the most important aspects of the professionalism of the teacher is his or her skill and creativity to develop strategies to cope with differences in the group. It does 
not really matter whether these differences are differences in reading-skills, in foreknowledge, or in this case, differences in religious backgrounds. This is common to them and an everyday practice to do and to reflect upon.

So then, now that we have explored the teacher's relationship to both of the single components, the final question can be asked again: Does the teacher - at work in the field of tension between the component Formal Christian identity of the school and the component Religious diversity in the school and in the classroom - does he or she actually experience and interpret that as a strained relationship? The answer is - as we stated earlier - that they experience very little tension between the two components.

We evaluate these findings as being remarkable. Firstly, because it is against the expectations one would have from literature and from the analysis of the political debate. And secondly, because of the discrepancy between implicit and explicit identity perceptions. If the teacher is asked to reflect explicitly on the formal, Christian identity of his or her school as such, then the responses prove to be problematic. While in the everydaylife there is hardly any tension and is this teacher contributing to the identity of the school all the time.

How to explain this? A superficial explanation could be that teachers are not experiencing urgent and immediate causes for reflection on the formal Christian identity of their schools. Since such an entity is not often stressed, then - in the teachers mind - the two components could not be experienced as opposed to each other in a hypothetical field of tension. One of the components does not exist at all, because they are not so much aware of it. Leave aside the question whether the two components are in a good or bad relationship. The notion identity of the school proves to be an abstract concept that exists rather isolated from daily practices in school and is not really related to this practice (all of course in the perception of the teachers).

A less superficial explanation could be the following. We noticed that by the research interviews the teacher was challenged to reflect on his or her perception of formal identity, and to give words to it. All of them at a first glance interpreted Christian identity in a narrow sense, i.e. in relationship to explicit religious notions, rituals and practices. When started with a reflection and explanation of it, they immediately tend to reason in a deductive scheme. While in their daily practices they continuously make decisions how to behave professionally, which proves to be done in an inductive way of reasoning. Of course in this latter process the topical identity of the school is generated continuously (cf. reasoning B). A linking of this latter inductive process of identity construction with the former primarily deductive perceived formal Christian identity of the school proves to be out of sight.

The other component in our supposed field of tension (the religious diversity in the group) is just a typical example or feature of the daily practice in the school. This daily practice is known to the teacher. And notwithstanding the fact that it requires a continuous reflection and decision-making, he or she feels at home there. Nonetheless these decisions presuppose values and priorities. So, the daily decision-making is closely linked to the identity of the school if we consider the inductive mechanism of reasoning. It is remarkable that decision-making regarding the religious diversity of the group is not perceived as difficult and that there is not so much a barrier to discuss this with the interviewer.

We conclude that in the perception of the teacher the field of tension between the formal Christian identity of the school and the religious diversity in the group does not really exist. Hardly any tension is felt between the two, mainly because the two components can not really be placed opposite to on another. The main reason for this is that firstly the first 
component receives not much attention in the mind of the teacher, and secondly the way of reasoning is fundamentally different. The reasoning around the school's identity does not really meet the reasoning on the role of values in the daily decision-making in educational practices. The first is mainly conceptualised and perceived by a deductive mechanism; the second by an inductive mechanism. The way of reasoning around the two components of our scheme is fundamentally different, which does not make a linking between the two obvious and self-evident.

\section{A Mixture of Global and Typically Dutch}

Having discussed the conclusions of our Research Project A, we stated that there is a need for a paradigm shift towards a more inductive reasoning on the school's ethos and identity (Bakker and Rigg, 2004:201-205). This recommendation is based on the desire to bring the reflection on formal identity closer to the more inductive mechanism of reflection on daily practices. For the teacher this mechanism proves to be more natural, more obvious and selfevident. Another great advantage is that this approach seems to include reflection on the values and priorities that play an integrated role in the daily decision-making, more naturally.

Some remarks on this conclusion: Firstly, to argue in favour of a more inductive approach of religion and values is not new. In fact, many authors have already argued for this approach (cf. Geertz, 1973; Taylor, 1994; Smith, 1962; Giddens, 1986; Chidester, Stonier and Tobler, 1999; Heimbrock, Scheilke and Schreiner, 2001; Jackson, 1997; 2004). Secondly, that there is still the need to change a paradigm in education from a more deductive towards a more inductive mechanism of reasoning, if it concerns the formal identity of the school could be typically Dutch. ${ }^{7}$ We think that this change has come and is to come relatively slowly, because the deductive way of reasoning is so tightly rooted and legitimised in Dutch society, i.e. the history of the pillarised society in general, and more specifically the history of the pillarised educational system. Thirdly, the challenge is now to apply the new paradigm to the reflection on the schools ethos and identity. A shift that has already effectively taken place in societal domains like politics, broadcasting companies, sports clubs, etc. Fourthly, the consequence of all this is that the debate on the essence of the Christian or religious character of education preferably should not start in abstracto, or on the level of the (e.g. protestant-Christian) pillar or on the level of the school boards. The preferred debates and the explorations should be initiated in every single school, in talks and deliberations in the field. This is a debate that is supported and actually fed by the teachers who teach in those particular schools - a school that has already a certain ethos and identity. Upon this, reflection is needed and useful.

\section{Project B: Our Experimental Garden: Structural Debate on the School's Ethos}

Taking up the consequences of the former paragraph, in schools in some of the bigger cities in the Netherlands, we organise structural debates on the schools' ethos. Not with the ambition to cover and to change the whole of education in the Netherlands, and finally not to make Dutch education reflect in the right way. That would be nonsense, and - being academics - it is not our most important ambition. By doing so, we would like to create an experimental garden to get experienced in the processes on-the-job. The aim is to develop and explore strategies to organise types of structural reflection (Bakker and Ter Avest,

Of course with neglecting all kind of different positions of schools (within and between). 
2003). Since 1998 our research team has been running projects in 32 primary schools and five secondary schools. The leading idea is to facilitate fundamental talks between teachers on a regular basis and on a track of at least two years. The evaluation of these processes and our own reflection during the execution of the job should meet the standards of academic research.

It is again that we notice, but this time it is in this project, that in daily practice a teacher experiences only a few stimuli to reflect on the formal identity of his or her school. Teachers are mainly triggered to reflect upon the formal Christian identity of the school, when they become fully aware of the differences in the background of life views of the parents of their pupils. In addition to this, we observe and confirmed the notion of school ethos, in Dutch called specifically the identity of the school, as perceived in a narrow understanding. It is in the first place e.g. the subject of RE that causes problems in a plural context. So, an invitation to the teaching team to have a discussion together on the Christian identity of our school very often is interpreted as an invitation to talk about religious feasts, daily rituals, and for example the question what to do with Muslims in our Christian school, etc. These subjects and the discussion about the related concrete topics are very unpopular among teachers. Their professional biography very often is composed of stories of this type of talks in the past and more often than not they are frustrated by this. The cause of the frustration is to be found in the character of this type of meetings. In those school assemblies teachers were invited to express their criteria and opinions: Their agreement, upon for example, a statement like: In the board of parents of our school, every parent should be a member of a Christian religious community, or: Since we are a Christian school every teacher should say a prayer with her pupils at the beginning and at the end of the day. During such a meeting teachers argued about the pro's and con's of the statement, which very often ended up in a mutual lack of understanding, controversy and feelings of discomfort and inconvenience. Very often a person involved in this type of discussion uses the narrow conception of identity. Their initial interpretation is the narrow understanding of the identity-issue combined with negative emotions, so they are not very much willing to step into these projects. And if he or she does, then they feel themselves invited to reason in a deductive way. They expect that the board, or the general directing bodies, already have a concept in mind and that reflection on identity means reflecting how this concept should be applied in my practice as a teacher. It raises the feeling of being controlled or being directed. Instead of expressing their commitment to a topic like prayer, teachers use arguments to underline the right way of handling the problems of prayer. Very often the atmosphere is one of debating and trying to convince one another. At least we could learn from the negative feelings of discomfort and inconvenience at the end of the meeting, that the topic is experienced as an important and triggering topic to every participant. Initiating discussions on the identity of the school bears the risk of a selffulfilling prophecy.

The remedy we suggest is a radical inductive approach. Instead of interpreting the negative feelings of the persons involved as troublesome, these feelings are viewed and interpreted as proofs for their commitment - be it a negative involvement. The exploration of this involvement is the aim of our inductive approach in the school meeting, instead of arguing about opinions and procedures. Elementary forms of the more complex Self Confrontation Method (SCM) ${ }^{8}$ are used to support the teachers of the school team in exploring their personal emotional commitment to important issues related to the school's identity. In this process of school-identity

8 The Self Confrontation Method is based on the valuation theory and the theory of the Dialogical Self (Hermans and Hermans-Jansen, 1995). 
formation, we ascribe special influencing and motivating forces to the director of the school. That is why we use, in addition to the elementary forms, the more comprehensive and complete SCM to explore relevant topics with the director and sometimes also with the co-director of the school. We use an instrument with diagnostic and developmental characteristics. In a process of co-operation the (co-) director and the researcher explore the affective commitment of the (co-) director and his motivations concerning the identity of the school. This exploration generates a deeper insight into the roots of his basic motivations, which results in the formulation of a life theme and a normative concern, which could be interpreted as a fundamental of his professionalism.

This radical inductive approach proves to be a surprising way of making educational interventions. We still emphasise the so called identity of the school, but what we essentially do is to trigger teachers to develop themselves by reflecting and evaluating their own practices. This reflection, however, gets through the level of the daily practice to the layer of valuations and basic motivations, rooted not only in the professional biography, but even more in the personal biography. Thus, it is a three-layered reflection.

In contextual orientations on the potentials of these projects and this approach, many points of relevance could be discovered. If identity of a school is understood in a broader sense, a lot of work is done for that already, but it seems to be done in another language. It is about the mission of the school, the school atmosphere, school climate and school ethos, topics and concepts that are part of the parcel of PR-documents and in paragraphs of official documents. Despite the mission of the school and the school ethos about values and value orientation, it seems not to be recognised explicitly. Elementary forms of the SCM as well as its comprehensive approach stimulate the understanding that decisions in the daily professional practice, but also in the official documents on the mission of the school and school ethos, are essentially normative. For us a leading principle is the statement that a teacher is a professional and that every professional is supposed to be trained not only in skills and techniques, but also in a deliberate decision making that is essentially normative and in which life-orientation is central. This idea of a normative professionalism and the provocation of a three-layered reflection on it are crucial in the approach we develop. It concerns identity in a broader sense (religious feasts and issues on class room behaviour are both covered) and it is inductive in its reasoning (because individual biographies and experiences are unavoidably needed in those deliberations).

The most interesting part of project is that this type of inductive and contextual reflection by teachers is not self-evidently linked to the formal identity(-ies) of the school. This is in line with the results of the research project Teachers on a tense footing.

\section{Conclusion}

The challenge is to organise and facilitate a paradigm shift and at least to elaborate the meaningful stories from the research in such a way that it could meet and/or match with conceptions of formal identities of schools. The challenge of the current project is to elaborate and to make a narrative identity more concrete with the aim to build from that an explicit image of the school's ethos.

It is not our ideal to make the right matching between the provoked narratives and the formal conceptions of identity, but it is more that teachers should tell what they think is meaningful, and how they reflect in a threefold way on the meaning of their professional behaviour. It is in these stories that the authentic characteristics and profile of the school is actually generated. This $i s$ the identity of the school, be it in a dynamic mode. 


\section{BIBLIOGRAPHY}

Bakker, C 1999. Diversity as ethos in intergroup relations. Diversity as ethos: Challenges for Interreligious and Intercultural education, eds. Chidester, D; Stonier, J \& Tobler, J. Cape Town

-- 2002. Hoe geef je vorm aan de identiteit van de school? in: Siebren Miedema \& Henk Vroom. 97-124.

-- 2001. School as a Place of Diversity. Towards Religious Competence: Diversity as a Challenge for Education in Europe. Heimbrock, H-G, Scheilke, GT, Schreiner, P. Münster: LIT Verlag \& New Brunswick (USA)/London (UK): Transaction Publishers. 203-221.

-- 2004. Demasqué van het christelijk onderwijs?; Over de onzin en zin van een adjectief (Inaugartion lecture). Utrecht: Faculteit of Theology.

Bakker, C and Ter Avest, I 2003. Structureel Identiteitberaad (SIB) op vier PCBO scholen; Van pilot naar strucuur. Utrecht.

Bakker, C and Griffioen, K (eds.) 2001. Religious dimension in intercultural education: Theory and good practice. Oisterwijk: Dutch University Press.

Bakker, C and Rigg, E 2004. De persoon van de leerkracht; Tussen christelijke schoolidentiteit en leerlingendiversiteit. Zoetermeer: Meinema.

Beck, U 1986. Risikogesellschaft; Auf dem Weg in eine andere Moderne. Frankfurt.

Chidester, DJ; Stonier, J and Tobler, J (eds.) 1999. Diversity as ethos: Challenges for Interreligious and Intercultural education. Cape Town.

Dewey, J 1938. Experience and Education. London/ New York.

De Wolff, Anneke 2000. Typisch christelijk?; Een onderzoek naar de identiteit van een christelijke school en haar vormgeving. Kampen: Kok.

Durkheim, E 1992. De elementaire vormen van het religieuze leven. Leuven: Acco.

Everington, J and Sikes, P 1998. Daring to be an RE Teacher; A Life History Approach to Becoming an RE Teacher. Paper presented at I SREV. Wales.

Geertz, C 1973. The interpretation of cultures. New York.

Giddens, A 1986. The Consequences of Modernity. Cambridge: UP.

Heimbrock, HG, Scheilke CT, Schreiner P. Towards Religious Competence: Diversity as a Challenge for Education in Europe. Münster: LIT Verlag \& New Brunswick (USA)/London (UK): Transaction Publishers

Hermans, CAM 2003. De school als gemeenschap. Participerend organiseren van identiteit. Budel: Damon.

Jackson, R 1997. Religious Education; An interpretive approach. London: Hodder \& Stoughton.

-- 2004. Rethinking Religious education; Issues in diversity and pedagogy. London/New York.

Kelchtermans, G 1991. De professionele ontwikkeling van leerkrachten vanuit het biografisch perspectief. Nederlands Tijdschrift voor Opvoeding, Vorming en Onderwijs. 7(3).

Kelchtermans, G and Vandenberghe R 1990. Het biografisch perspectief in onderzoek van het professioneel handelen van docenten. Pedagogisch Tijdschrift. 15(3). 
Klaassen, C 1996. Socialisatie en Moraal, Onderwijs en Waarden in een Laat-moderne Tijd. Leuven/Apeldoorn: Garant.

Korthagen, FAJ; Kessels, J; Koster, B; Lagerwerf, B and Wubbels, T 2001. Linking theory and proactice; The pedagogy of realistic teacher education. Mahwah, NJ: Lawrence Erlbaum Associates.

Korthagen, FAJ and Lagerwerf, B 1996. Reframing the relationship between teacher thinking and teacher behaviour: Levels in learning about teaching. Teachers and Teaching: Theory and Practice, 2(2).

Korthagen, FAJ 1998. Leraren leren leren; Realistisch opleidingsonderwijs, geïnspireerd door Ph.A. Kohnstamm. Amsterdam: Vossiuspers AUP.

Korthagen, FAJ 2001. Waar doen we het voor?: Op zoek naar de essentie van goed leraarschap. Utrecht: WCC.

Kuiper, 1994 Kuiper, D.Th., H. Klifman, e.a. 1992. Niet bij kennis alleen: de toekomst van het christelijk onderwijs in de Nederlandse samenleving.

Kunneman, H 1996. Normatieve professionaliteit: een appel. Sociale Interventie. 1996(3).

Kunneman, H 1997. Een postmoderne hermeneutiek als wetenschaps-theoretisch kader voor kwalitatief onderzoek. Kwalitatief onderzoek en levensbeschouwing, eds. Smaling, A \& Hijmans, E (red.). Amsterdam: Boom.

Lanser-Van der Velde, A 2000. Geloven leren; Een theoretisch en empirisch onderzoek naar wederkering geloofsleren. Kampen: Kok.

Miedema, S 2003. De onmogelijke mogelijkheid van levensbeschouwelijke opvoeding. Amsterdam: VU.

Rickers, Folkert, Dirk Chr. Siedler. Interreligiöses Lernen in den Niederlanden: Ein Beitrag zur Vergleichenden Religionspädagogik. Berlin: Alektor Verlag.

Roebben, B 2000. Religieus opvoeden in een multi-culturele samenleving. Leuven: Garant.

Smith, WC 1962. The meaning and End of Religion. New York.

Taylor, C 1994. Multiculturalism; Examining the Politics of Recognition. Princeton: UP.

Van den Berg, R and Ros, A 1998. Analyse van de subjectieve realiteit van docenten bij onderwijsvernieuwing. Pedagogische Studiën. 75:36-51.

Van den Berg, R and Vandenberghe, R 1995. Wegen van betrokkenheid; Reflecties op onderwijsvernieuwing. Tilburg: Zwijsen.

Van Parreren, CF 1988. Ontwikkelend onderwijs. Amersfoort/Leuven: Acco.

Vroom, HM 1996. Religie als ziel van cultuur; Religieus pluralisme als uitdaging. Zoetermeer: Meinema.

Wardekker, W and Miedema, S 2001. Religious Identity Formation between Participation and Distantion, in: Heimbrock, H-G, Scheilke, CT, Schreiner, P. 203-221.

Zondag, HJ 1993. Een taak met ruimte: Onderwijsgevenden van confessionele basisscholen: persoonlijke levenbeschouwing, houding tegenover het godsdienst onderwijs en relatie met rolzenders. Proefschrift Katholieke Universiteit Nijmegen. 